\title{
A Review: Interactions of Equine Herpesvirus-1 with Immune System and Equine Lymphocyte
}

\author{
Nor Dini Rusli, Khairiyah Binti Mat, Hasnita Che Harun \\ Faculty of Agro Based Industry, Universiti Malaysia Kelantan, Jeli Campus, Kelantan, Malaysia \\ Email: nordini@umk.edu.my
}

Received 11 October 2014; revised 26 November 2014; accepted 8 December 2014

Copyright $@ 2014$ by authors and Scientific Research Publishing Inc.

This work is licensed under the Creative Commons Attribution International License (CC BY).

http://creativecommons.org/licenses/by/4.0/

(c) (i) Open Access

\begin{abstract}
Equine herpesvirus-1 (EHV-1) remains one of the most common viral pathogens affecting horses worldwide presenting as a persistent infection which can establish latency in nerve ganglia (trigeminal ganglion), lymphoid tissues of the respiratory tract and peripheral blood lymphocytes. EHV-1 infection induces both humoral and cellular immune responses in horses. Virus neutralising antibody, particularly in the nasopharynx, is to kill free virus shed from infected epithelial cells. Hence this antibody has important functions in reducing virus shedding and spreading infection to cohorts. Cellular immune responses, particularly those carried out by cytotoxic $\mathrm{T}$ lymphocyte (CTL), have been shown to be effective in killing virus-infected cells in vitro. This review underlines the state of knowledge regarding immunity to EHV-1 and also its interaction with equine lymphocyte. Finally, the review also includes the importance of the viral immediate early (IE) protein in the pathogenesis of EHV-1. This information can be used as the basis for future research.
\end{abstract}

\section{Keywords}

Equine Herpesvirus-1 (EHV-1), Lymphocyte, Cytotoxic T Lymphocyte (CTL), Immune Response, Peripheral Blood Mononuclear cell (PBMC)

\section{Introduction}

Virus infections are the most common human disease, particularly acute respiratory infections. In horses, viral respiratory infections are also common and the most notable viral pathogens are equine herpesvirus-1 (EHV-1), equine herpesvirus-4 (EHV-4), equine influenza virus (EIV) and equine arteritis virus (EAV) [1] [2]. 
EHV-1 is a ubiquitous pathogen of all breeds of horses and other equids worldwide. It can cause respiratory and neurological disease as well as abortion in pregnant mares and it remains responsible for major economic and welfare problems. Studies of virus-specific immune responses have played essential roles in the development of diagnostic techniques and the evaluation of new strategies for vaccination. Both humoral and cellular immune responses are important in protection and recovery from EHV-1 infection and the relative importance of these responses has been the subject of much investigation. For example, although virus neutralising (VN) antibody specific for EHV-1 in serum can be associated with a reduction in the amount and duration of virus shed, there are no significant effects on cell-associated viraemia [3], although a previous paper [4] indicated that VN antibody stimulated by vaccination did reduce the cell-associated viraemia but the mechanism is unknown. The perceived failure of VN antibody to affect the cell-associated viraemia is because most viruses become intracellular soon after landing on the respiratory mucosal surface and killing of cell associated virus is the major function of cytotoxic T lymphocytes (CTL) [5]-[8].

Current commercial vaccines that contain inactivated virus give only partial clinical and virological protection against respiratory infections with EHV-1 because they do not stimulate CTLs and therefore do not control the cell-associated viraemia which disseminates virus from the respiratory tract [9]. CTLs are stimulated after both experimental and natural infection with EHV-1 [5] [9] and it has been shown that CTL precursor (CTLP) frequency is the major correlate of immunity to this virus [7] [8]. The product of the EHV-1 immediate early (IE) gene 64 (Figure 1) has been shown to be a target for EHV-1 specific CTL restricted by the B2 allele on the equine leukocyte antigen A3 (ELA-A3) haplotype [9] [10].

\section{Pathogenesis of EHV-1}

EHV-1 infections in horses may become established because of exposure to infectious virus by the respiratory route or by reactivation (recrudescence) of latent virus elsewhere in the body [11]. New infections are acquired by inhalation of infectious aerosols or contact with infectious secretions. After inhalation, viral replication occurs in the epithelia of the upper respiratory tract, including turbinates, pharynx, soft palate and tracheal epithelium [12]. The virus penetrates the epithelial barrier and by infecting a wide range of cell types, including immune cells, moves into deeper tissues of the respiratory tract and into the draining lymph nodes via lymphatic drainage (Figure 2). Subsequently, a second stage of viral replication occurs in which EHV-1 replication can be demonstrated in lymph nodes by the isolation of infectious virus and the presence of viral antigen in mononuclear cells of the retropharyngeal and submandibular lymph nodes from 12 hours post infection [13] [14].

From 4 to 6 days post infection, the infected lymphocytes migrate from lymph nodes into the blood, resulting in a cell-associated viraemia and then EHV-1 is carried by infected peripheral blood mononuclear cells (PBMC) and spreads throughout the body. By this method, the cell associated virus may disseminate to internal organs such as the uterus and nervous system (Figure 2) [15]. In the uterus, infected lymphocytes adhere to the endothelial cells in small blood vessels supplying the placenta. This endothelial cell infection initiates the formation of protein clots, leading to thrombosis and vascular damage [16] [17]. Inflammation of blood vessels (vasculitis) develops, leading to damage of the placenta and thus the virus spreads to the fetus and consequently results in the abortion (Figure 2) [18] [19]. It is suggested that the uterine pathology and/or fetal distress initiates a physiological cascade, resulting in the separation of the placenta from the endometrium [9] [20]. In the early 1990s,

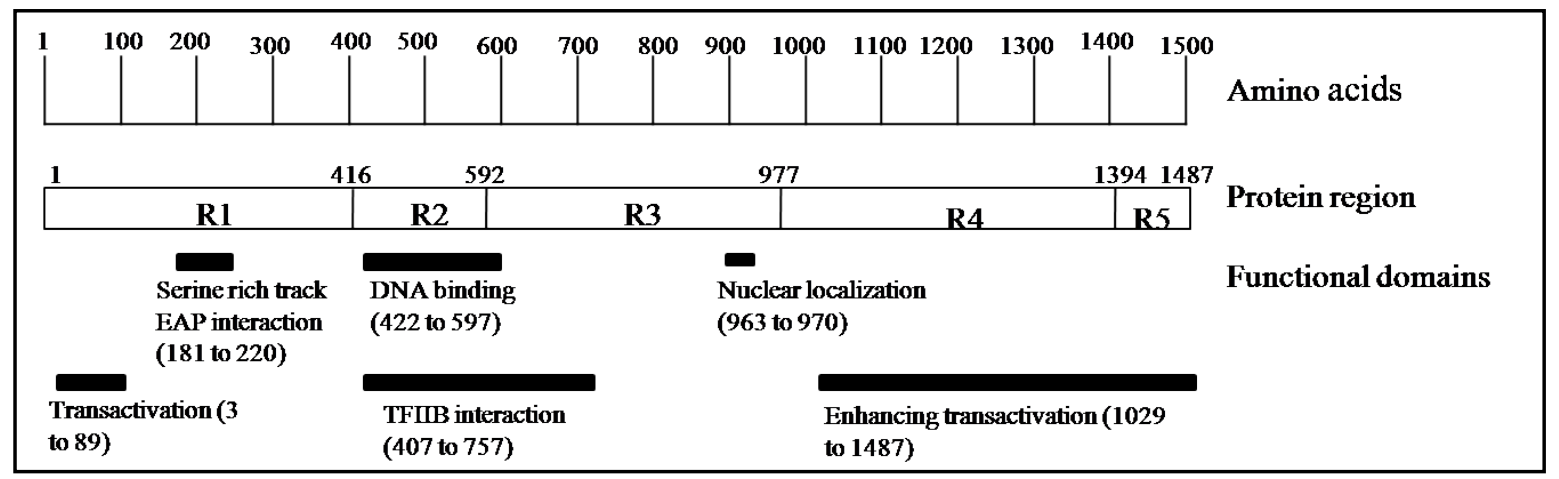

Figure 1. Schematic representation of the EHV-1 immediate early gene. 


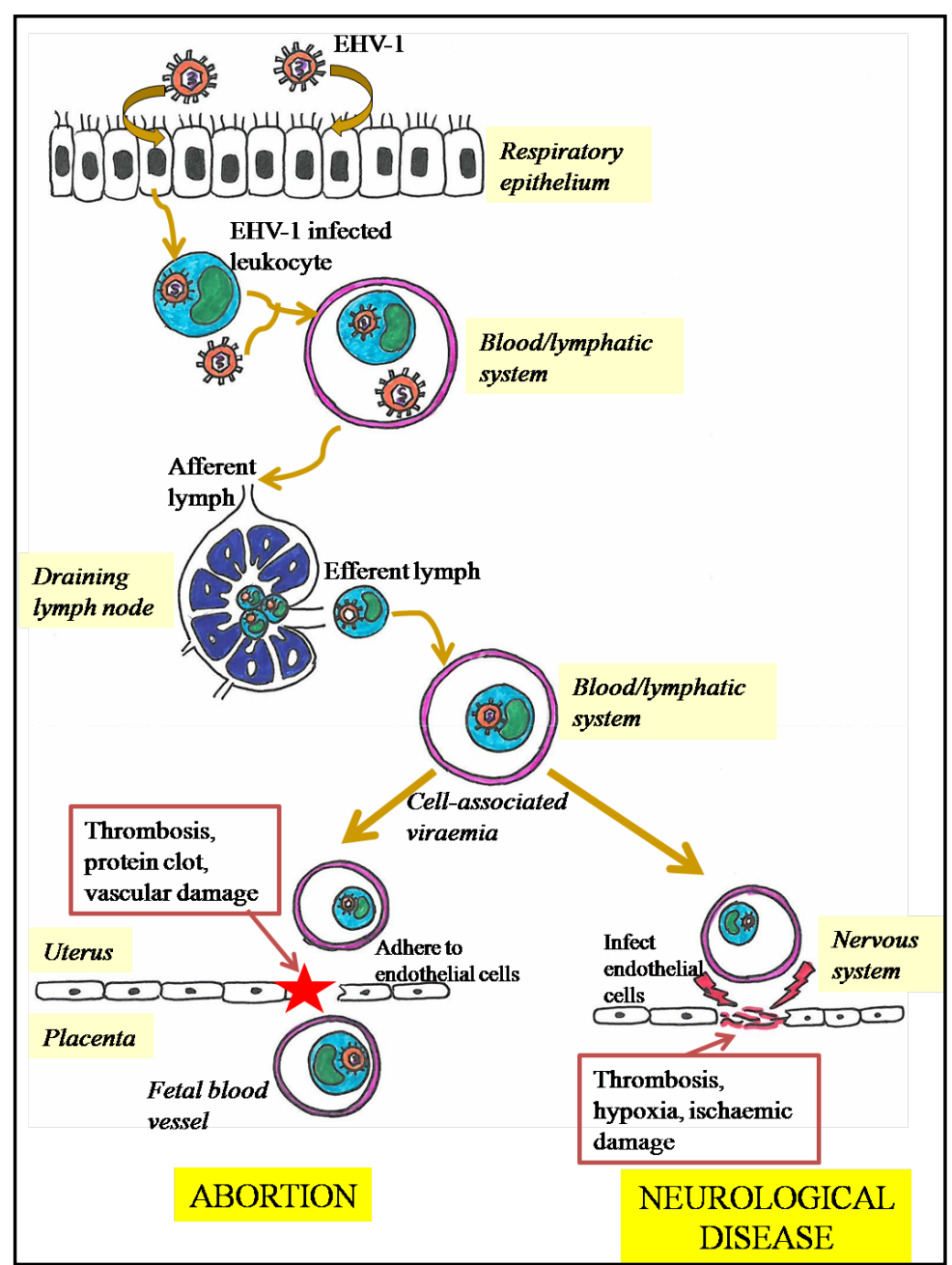

Figure 2. Schematic diagram of EHV-1 pathogenesis.

some studies reported that viral replication and vascular damage were more prevalent in the late pregnant uterus [17] than in the early pregnant uterus [21]. The causes of these differences in the early and late pregnancy are still unclear.

Neurological disease is a consequence of EHV-1 infected PBMC reaching the nervous system and causing infection of vascular endothelia of small arterioles and venules (Figure 2). Immune complexes may play a key role in this pathogenesis as some studies observed that recovery of virus from the central nervous system frequently failed [22] [23]. Edington et al. [24] provided evidence that EHV-1 can infect endothelial cells of the blood vessels of the nervous system and that this results in vasculitis, leading to thrombosis, hypoxia and secondary ischaemic damage, which compromises the blood supply to neurones and results subsequently in nervous system disorders (Figure 2) [15].

As with other alpaherpesvirinae, EHV-1 establishes latent infection and persists in its host, following a primary infection. During latency, the expression of the EHV-1 genome is repressed and only a viral RNA transcribed from the IE gene occurs giving rise to a latency-associated transcript (LAT). However the precise function of LAT is not well understood and no infectious virus is produced [25]. The locations of EHV-1 latency were identified as the trigeminal ganglion [26] [27], in lymphoid tissue draining the respiratory tract [26] [28] [29] and in peripheral blood leukocytes [28]-[30]. Smith et al. [30] reported that $\mathrm{CD}^{+} / \mathrm{CD}^{+} \mathrm{T}$ lymphocytes were the predominant site of EHV-1 latency in peripheral blood leukocytes. In 2000, one study demonstrated that alveolar macrophages were also a site of latency by detecting the latent transforming growth factor $\beta$ in alveolar macrophages [31]. 


\section{Interaction of EHV-1 with the Immune System}

Attempts to identify immune responses which correlate with protective immunity against re-infection have been made, so that they can be stimulated by vaccination. However they have proved difficult to identify. Generally, herpesvirus infection, particularly EHV-1 infection involves a local immune response at the primary site of replication as well as a systemic immune response which consists of antibody, cytokine and cellular components.

\subsection{Antibody Responses}

In the past, serological assays were developed in order to measure serum antibodies with $\mathrm{VN}$ and complement fixing (CF) activity in vitro [32] [33]. These diagnostic techniques demonstrated VN, which is also called serum neutralising (SN) and CF antibodies appear in the sera of infected horses and are demonstrable from two weeks after experimental EHV-1 infection, up to 1 year or less than 3 months respectively [33] [34]. VN antibodies are largely type specific for a foal immunised with an inactivated EHV-1 vaccine, however there was cross reactivity after immunisation with inactivated EHV-4 [35]. VN antibodies are directed primarily against epitopes on glycoproteins $\mathrm{gB}$ and $\mathrm{gC}$ as recognised by the immune system of horses infected or vaccinated with EHV-1 [34]. In contrast to the VN antibodies, CF antibodies are usually undetectable by 3 months after infection. The epitopes recognised by CF antibodies are cross reactive with EHV-1 and EHV-4 proteins, resulting in an inaccurate diagnosis using CF antibodies alone [36].

Previously, EHV-1 antibody in serum samples was tested by several methods; a serum neutralisation (SN) which is equivalent to a VN test, a CF test and the EHV-1 gG specific enzyme-linked immunosorbent assay (ELISA). The antibody titres increased in animals experimentally infected with EHV-1 on day 14 post-infection [4] [37]. Sera samples were previously assessed using EHV-1 gG specific ELISA, detecting antibodies against both EHV-1 and EHV-4 in Crabb et al. [38]. ELISA was also performed to detect EHV-1 specific IgG isotype and IgA antibodies in serum and nasal secretions [39]. The SN test can detect high SN titres following infection or vaccination within 3 months [40] and for up to 1 year after infection [34]. Goehring et al. [4] also found that the SN test could cross-react with the EHV-4 strain which is similar to the CF assay, therefore the results may vary. In the horse, there are five IgG subclasses; IgGa, IgGb, IgGc, IgG (T) and IgG (B), the latter is an aggregating immunoglobulin; and these have been investigated using mAbs specific to IgG subisotypes [41] [42]. In 2004, the horse Ig heavy chain constant region (IGHC) genes which encoded one IgD, one IgM, one IgA, one IgE and seven IgG isotypes were described. All seven genes of IgG heavy chain constant in horses were expressed in vivo [43]. In addition, it described the gene encoding equine IgD [43]. This molecular analysis resulted in new nomenclature of the equine immunoglobulins; equine IGHD and IGHG7 genes. The antibody isotypes produced as a result of infection with EHV-1 have been characterised. Many nasal secretions contain antibodies primarily of the EHV-1 specific IgA type, while IgGa and IgGb were the main isotype responses in serum [39] [44] [45]. Breathnach et al. [44] analysed EHV-1 specific antibody responses by monitoring equine IgGa, IgGb, IgG (T) IgA and IgM in nasal wash samples from weanling foals after primary and subsequent experimental infections with a virulent EHV-1 using an ELISA. IgA was the major antibody isotype detected throughout the sampling period for 13 weeks in nasal mucosa. The mucosal IgA with VN activity was stimulated after experimental primary EHV-1 infection. The IgA response was short lived after a single infection, but it persists longer with subsequent infections until at least 26 weeks. Other studies have also reported that IgA is the primary antibody isotype at the nasal mucosa for protection of horses against several upper respiratory tract pathogens such as Streptococcus equi [46], EIV [47] [48].

Comparing the SN titres with kinetic ELISA IgG subclass anti-EHV-1 antibody responses, the IgGa and IgGb responses showed similar results and IgGb isotype responses appeared to associate well with the pattern of SN responses [37] [39]. Although the role of equine IgGc isotype has not been described yet, this isotype response was also measured but it was negligible between infection groups in the kinetic ELISA. It was remarkable that there was a pre-existing IgG $(\mathrm{T})$ response in all experimental horses although SN titers had gradually declined at this time point, indicating IgG (T) response is unlikely to be associated with humoral immunity to EHV-1 [37]. A study by Goodman et al. [49] demonstrated that the IgGb/IgG (T) ratio may be able to protect against EHV-1 infection as the IgGb responses was high in horses administered an inactivated virus vaccine and the horses were partially protected from neurological disease, viral shedding and clinical signs.

\subsection{Cytokine Responses}

Numerous studies have described cytokine responses to EHV-1 infection by screening for the presence of cyto- 
kines’ nucleic acid or protein, for example interferon gamma (IFN $\gamma$ ), interferon alpha (IFN $\alpha$ ), interleukin-4 (IL4), interleukin-10 (IL-10), tumor necrosis factor (TNF- $\alpha$ ) [37] [50]-[53]. Interferons were detected in nasal secretions and serum during the first 10 days after experimental EHV-1 infection of ponies [54]. IFN type I which consists of IFN $\alpha$ and IFN $\beta$ was detected in the upper respiratory tract. In other species, both these IFNs are very important for protection against viral infection by increasing the synthesis of major histocompatibility complex (MHC) class I molecules in the infected cells, thus making them more susceptible to killing by $\mathrm{CD}^{+} \mathrm{CTLs}$ [55]-[58]. Apart from type I IFNs, a single type II IF N called IFN $\gamma$ has an important role in the adaptive immune response to intracellular pathogens. A study demonstrated that a monoclonal antibody (mAb) cross reacts with equine IFN $\gamma$ produced by PBMC [51]. This equine IFN $\gamma$ marker, mouse anti bovine IFN $\gamma$ mAb (clone CC302, IgG1 isotype) detects expression of this protein in PBMC following the flow cytometric analysis [51] [59]. Another study also used the same mAb to measure antigen-specific IFN $\gamma$ synthesis by equine lymphocytes in order to compare post EHV-1 infection PBMC samples to pre-infection samples [60]. EHV-1 stimulated PBMC collected 10 days post-infection induced a higher percentage of $\mathrm{CD}^{+}$and $\mathrm{CD}^{+}$IFN $\gamma^{+} \mathrm{T}$ lymphocyte subsets, suggesting that it may contribute to protective immunity to EHV-1 [60]. The percentage of IFN $\gamma^{+}$cells following in vitro stimulation with EHV-1 was undetectable in foals, but increased with age [51] or after vaccination with a vaccinia-virus construct coding for the EHV-1 gene 64 [61]. This increase in antigen specific T cells may indicate that EHV-1 specific memory cells can be boosted after subsequent challenge infection or vaccination with appropriate antigens. Another study also reported that ponies repeatedly infected with EHV-1 showed IFN $\gamma$ responses to EHV-1 [52]. The frequency of EHV-1 specific cells was also investigated in a large population of Thoroughbred horses and the results demonstrated higher numbers of IFN $\gamma^{+}$cells in older horses; among 2 year olds and vaccinated horses [62]. After in vitro EHV-1 stimulation, the IFN $\gamma^{+}$cells were phenotyped and predominantly associated with $\mathrm{CD}^{+}$cells [50] [51]. These studies also compared the frequency of cytotoxic $\mathrm{T}$ lymphocyte precursors (CTLP) with the number of $\mathrm{CD}^{+} / \mathrm{IFN} \gamma^{+}$lymphocytes and showed a similar pattern. CTLp are the precursors of CTL found in peripheral blood which develop effector cytotoxic activity in vitro following incubation of PBMC with EHV-1 for approximately 7 days. Therefore, the IFN $\gamma$ synthesis by $\mathrm{CD}^{+}$ cells may be used as an alternative indirect measure for CTL activity against EHV-1.

MAbs that specifically detect equine IL-4, IL-10 and IFN $\gamma$ have been generated and tested in ELISA and intracellular staining to measure these important cytokines [53] [63] [64]. The first multiplex assay for equine cytokines has also been developed to allow simultaneous analysis of IL-4, IL-10 and IFN- $\alpha$ in horses [65]. The measurement of cytokine mRNA in conjunction with polymerase chain reaction (PCR) has also been widely performed to illustrate the stimulation of immune response after infection or vaccination against viruses such as EIV [66]-[68], equine infectious anaemia virus (EIAV) [69] [70] or Rhodococcus equi [71]. In EHV-1, the upregulation of mRNA expression of IFN $\gamma$, IL-2, IL-4, IL-8, IL-10 has been shown in horses after experimental infection or vaccination against EHV-1 [37] [52] [72] [73].

\subsection{Cellular Immune Responses}

The cellular immune response is effective in controlling intracellular EHV-1 and consequently to reduce or eliminate the cell-associated viraemia [74]. Several techniques can be performed to assess the cellular immune responses including measurement of antigen-specific $\mathrm{T}$ cell proliferation, detection of CTL activity, cytokine mRNA expression and EHV-1 specific IFN $\gamma$ synthesis.

Proliferation of lymphocytes is commonly used as an indicator of immune status because proliferation usually precedes the development of effector functions. Previous studies examined the immune response to primary EHV-1 infection by incubating lymphocytes from infected horses with EHV-1 antigens (virus-specific lymphocyte response) [75]-[77] or with phytohemagglutinin (PHA), a lectin which stimulates a non-specific lymphocyte response [75] [76] [78] and by subsequent determination of the uptake of methyl tritiated thymidine $\left(\left[{ }^{3} \mathrm{H}\right]-\right.$ thymidine). Generally, these studies showed the proliferation of lymphocytes from reputedly primary infected horses towards EHV-1 antigens, suggesting previous, undetected exposure. Following the PHA response, Dutta et al. [75] and Bumgardner et al. [78] reported an increase of non-specific lymphocyte proliferation, but several other studies described a suppression of the non-specific lymphocyte proliferation [76] [79] [80]. To date, there is no study reported on the response of CTL effectors following a primary EHV-1 infection.

The CTL response is an essential part of the immune defence against many virus infections including EHV-1. EHV-1 becomes intracellular in lymph nodes within hours of contact with host cells, suggesting the importance of the cell mediated immune response to EHV-1 in vivo [12] [14]. After infection, CD8 ${ }^{+}$T lymphocytes increase 
in the blood and lung [81] [82]. However, studies of cellular immune response to EHV-1 in infection-immune horses have advanced by focussing on the role of CTL in the clearance of viraemic lymphocytes [83]. In Allen et al. [5], PBMC were collected from infected immune horses, cultured and restimulated with live, cell-free EHV-1 in vitro for CTLp stimulation. This study demonstrated EHV-1 specific CTLp as early as 1 week post infection with the highest level after 2 to 3 weeks. $\mathrm{CD}^{+} \mathrm{T}$ lymphocytes were also detected as the predominant lymphocyte population involving cytotoxic activity and restricted by MHC class I molecules. With regard to the local cell-mediated immune response, Breathnach et al. [44] analysed the response of CTLp and CTL effectors as well as the EHV-1-specific lymphoproliferative response indicative for Th cell activity from the nasal-associated lymphoid tissue and local draining lymph nodes nodes at 1 week post inoculation. They found the CTLp and CTL effectors were elicited ex vivo in all horses following EHV-1 inoculation, which suggested that EHV-1 infection can establish virus-specific memory CTL.

The frequency of CTLp was quantified by limiting dilution analysis (LDA) in PBMC of ponies before and after infection with EHV-1 [84]. The results showed that ponies with high numbers of CTLp were protected clinically and virologically against infection with EHV-1 whereas animals with low CTLp numbers were susceptible to infection [84]. When CTLp or memory CTLs are established by vaccination or prior to EHV-1 infection, they can differentiate and mature into CTL effectors which in turn will eliminate the infected target cells on re-infection. Instead of live, cell-free EHV-1 that was used in Allen et al. [5], Siedek et al. [85] used EHV-1 infected dendritic cells to restimulate PBMC in vitro. Following this stimulation, cytotoxic activity of EHV-1 specific CTLp was restimulated by equine dendritic cells which act as antigen presenting cells in vivo, suggesting that EHV-1 can infect dendritic cells in vitro.

Some studies using lymphocytes from animals infected experimentally with virulent strains of EHV-1 demonstrated a long-term suppression of the proliferation of lymphocytes to mitogen and viral antigen for periods varying between 2 and 10 weeks [79] [86]. The suppressive factor was associated with the increased levels of circulating activated transforming growth factor- $\beta$ and inhibited T cell response to PHA [79]. Hannant et al. [76] also described a decrease of the non-specific lymphocyte proliferation following the PHA response which was associated with cells, not serum. It was suggested that the immunosuppression may be due to the viral replication within the lymphocytes which interferes with the cells' ability to enter mitogenesis [87].

Identification of EHV-1 proteins which contain ELA-A restricted CTL epitopes is important as they may be included in recombinant or DNA vaccines [10]. In this study, PBMC were collected from ponies which had been primed to EHV-1 by previous infection. PBMC were then incubated for 1 week with equine dendritic cells transfected with individual EHV-1 plasmids encoding individual EHV-1 proteins, in order to stimulate autologous CTLp populations. Cytotoxicity was measured against EHV-1-infected PWM lymphoblast targets. This demonstrated that the IE protein elicited CTL responses [10] and later studies demonstrated that presentation of the IE protein's epitopes was restricted by the B2 allele of the ELA-A3 haplotype [9]. Although cytotoxicity assays are very useful for the measurement of CTL activity and frequency during the recovery phase of EHV-1 infection, they are time consuming and demanding. As an alternative, IFN $\gamma$ synthesis detected by intracellular IFN $\gamma$ staining in PBMC or enzyme-linked immunosorbent spot (ELISPOT) has been used as a measure of lymphocyte activation [51].

\section{Interaction of EHV-1 with the Peripheral Blood Mononuclear Cells (PBMC)}

The majority of studies have focused on the role of PBMC in EHV-1 viraemia which transmits the infectious virus from the primary site of infection to the vasculature of susceptible tissues. Some studies have reported which PBMC subpopulations are infected. An in vivo study was first performed in 1983 to identify infected PBMC by using PBMC from EHV-1 inoculated pony foals. The sub-populations of $\mathrm{T}$ and B lymphocytes and monocytes were separated to detect and quantify the presence of virus within these cells. Infected PBMC were detected at day 2 to 14, whereas the number of infected cells was maximal on day 4 post inoculation. The $\mathrm{T}$ lymphocyte population was identified as the most predominant cell type infected with EHV-1 during viraemia [88]. Furthermore, this study also suggested that pokeweed mitogen (PWM) can promote virus replication in PBMC as the virus was detected in a 10-high fold higher number of PWM stimulated cells. A similar study used in vitro infection of PBMC [89] with similar results. Subsequent in vitro work by Van der Meulen et al. [90] discovered EHV-1 replication in the resting monocytes after in vitro infection of PBMC as well as in T lymphocyte from mitogen stimulated PBMC. In an in vitro study, Gryspeerdt et al. [91] used two EHV-1 strains; 
neurovirulent and non-neurovirulent to inoculate ponies intranasally. Interestingly, both strains infected cells of the monocyte lineage $\left(\mathrm{CD} 172 \alpha^{+}\right)$rather than of T lymphocyte $\left(\mathrm{CD}^{+}\right)$in the mandibular lymph node and PBMC. In addition, Goodman et al. [92] also looked at the infected cells of all PBMC subpopulations in vitro using EHV-1 green fluorescent protein virus and reported that monocyte was the predominant infected cells. Another previous study demonstrated for the first time that EHV-1 is detectable in all PBMC subpopulations in vivo with $\mathrm{CD8}^{+}$lymphocytes and B lymphocytes the most frequently infected subpopulations [93].

\section{Immunomodulatory Properties of EHV-1}

During evolution, like other herpesviruses, EHV-1 has developed immune evasion mechanisms to avoid host immunity [94]-[98]. Numerous in vitro findings on EHV-1 immunomodulation have been reported [76] [79] [94] [99]-[101]. However, there are only few studies on the in vivo EHV-1 immune evasion mechanism [92] [97] [102] looking at the clinical outcomes and viraemia. Examples of the evasion methods are as follows. Immunosuppression involving a reduction of in vitro PBMC proliferation to mitogens and viral antigens following EHV-1 infection of ponies [76] [86], avoiding antibody-dependent immune responses by inhibiting cell surface expression of viral antigens [103], inducing down-regulation of MHC class I expression on infected cells [101] and inhibiting transporter associated with antigen processing (TAP) protein and blocking viral peptide transport to MHC class I molecules in the endoplasmic reticulum [94].

\section{EHV-1 Prospects}

Adaptive immune responses to EHV-1 have been widely studied [37] [44] [76] [83] [104]-[107]. EHV-1 promotes both humoral and cellular immune responses. VN antibodies appear approximately 2 weeks after EHV-1 infection [3] and function to reduce the amount and duration of nasopharyngeal virus shedding [3] [106], however, they do not play a major role in reducing cell-associated viraemia. However, one study indicates that a commercial vaccine which contains inactivated virus and thus stimulates VN antibody was successful in reducing the viraemia [4]. Cellular immune responses, particularly MHC class I restricted CD8 ${ }^{+}$CTLs are most crucial in protection against EHV-1 infection [7]-[9] [84] and it has been reported that the number of circulating CTLp offers an immunological correlate of protection from infection and recovery [7] [8] [84]. Consequently, rational design of new EHV-1 vaccines has focused on products with the best potential for stimulation of CTL responses and MLV which have been reported to perform the best [107].

Previous studies have demonstrated that the EHV-1 viral gene 64 (IE gene) acts as a target for effector CTL within the equine ELA-A3 MHC class I haplotype B2 allele [9] [10]. This information has proved crucial to understanding the development of cell mediated immunity specific for EHV-1. Taken together, these published research findings emphasise the importance of defining the EHV-1 target peptides in the IE protein encoded by gene 64 that may function as stimulators and targets for CTL restricted by the B2 allele, expressed on the ELAA3 genotype. The identification of target peptide is a logical step towards the development of new vaccines and offers great potential for construction of MHC class I virus peptide tetramers and the establishment of CTL lines and clones. These reagents will enable further understanding of the mechanisms which underlie the cellular immune response to EHV-1 in vivo and in vitro.

\section{Conclusion}

All findings mentioned in the review highlighted the importance of the viral IE protein in the pathogenesis of EHV-1 and as a target for effective immunity. This is the only identified CTL target protein for EHV-1. Further, this knowledge provides a potential basis for the future study which is to determine the dominant peptide(s) of the IE protein which is recognised by the immune system.

\section{References}

[1] Ostlund, E.N. (1993) The Equine Herpesviruses. Veterinary Clinics of North America: Equine Practice, 9, $283-294$.

[2] Mumford, J.A. (1992) Progress in the Control of Equine Influenza. In: Plowright, W., Rossdale, P.D. and Wade, J.F., Eds., Equine Infectious Diseases, VI. Proceedings of the 6th International Conference, R \& W Publications, Newmarket, 207-217.

[3] Hannant, D., Jessett, D., O’Neill, T., Dolby, C.A., Cook, R.F. and Mumford, J.A. (1993) Responses of Ponies to Equid 
Herpesvirus-1 ISCOM Vaccination and Challenge with Virus to the Homologous Strain. Research in Veterinary Science, 54, 299-305. http://dx.doi.org/10.1016/0034-5288(93)90126-Z

[4] Goehring, L.S., Wagner, B., Bigbie, R., Hussey, S.B., Morley, P.S. and Lunn, D.P. (2010) Control of EHV-1 Viremia and Nasal Shedding by Commercial Vaccines. Vaccine, 28, 5203-5211.

http://dx.doi.org/10.1016/j.vaccine.2010.05.065

[5] Allen, G.P., Yeargan, M., Costa, L.R.R. and Cross, R. (1995) Major Histocompatibility Complex Class I-Restricted Cytotoxic T-Lymphocyte Responses in Horses Infected with Equine Herpesvirus-1. Journal of Virology, 69, 606-612.

[6] Allen, G.P., Kydd, J.H., Slater, J.D. and Smith, K.C. (2004) Equid Herpesvirus-1 (EHV-1) and -4 (EHV-4) Infections. In: Coetzer, J.A.W. and Tustin, R.C., Eds., Infectious Diseases of Livestock, 2nd Edition, Oxford Press, Cape Town, 829-859.

[7] Kydd, J.H., Wattrang, E. and Hannant, D. (2003) Pre-Infection Frequencies of Equine Herpesvirus-1 Specific, Cytotoxic T Lymphocytes Correlate with Protection against Abortion Following Experimental Infection of Pregnant Mares. Veterinary Immunology and Immunopathology, 96, 207-217. http://dx.doi.org/10.1016/j.vetimm.2003.08.004

[8] Allen, G.P. (2008) Risk Factors for Development of Neurologic Disease after Experimental Exposure to Equine Herpesvirus-1 in Horses. American Journal of Veterinary Research, 69, 1595-1600. http://dx.doi.org/10.2460/ajvr.69.12.1595

[9] Kydd, J.H., Townsend, H.G.G. and Hannant, D. (2006) The Equine Immune Response to Equine Herpesvirus-1: The Virus and Its Vaccines. Veterinary Immunology and Immunopathology, 111, 15-30. http://dx.doi.org/10.1016/j.vetimm.2006.01.005

[10] Soboll, G., Whalley, J.M., Koen, M.T., Allen, G.P., Fraser, D.G., Macklin, M.D., Swain, W.F. and Lunn, D.P. (2003) Identification of Equine Herpesvirus-1 Antigens Recognized by Cytotoxic T Lymphocytes. Journal of General Virology, 84, 2625-2634. http://dx.doi.org/10.1099/vir.0.19268-0

[11] Allen, G.P., Bolin, D.C., Bryant, U., Carter, C.N., Giles, R.C., Harrison, L.R., Hong, C.B., Jackson, C.B., Poonacha, K., Wharton, R. and Williams, N.M. (2008) Prevalence of Latent, Neuropathogenic Equine Herpesvirus-1 in the Thoroughbred Broodmare Population of Central Kentucky. Equine Veterinary Journal, 40, 105-110.

[12] Kydd, J.H., Smith, K.C., Hannant, D., Livesay, G.J. and Mumford, J.A. (1994) Distribution of Equid Herpesvirus-1 (EHV-1) in the Respiratory Tract of Ponies: Implication for Vaccination Strategies. Equine Veterinary Journal, 26, 466-469. http://dx.doi.org/10.1111/j.2042-3306.1994.tb04051.x

[13] Patel, J.R., Edington, N. and Mumford, J.A. (1982) Variation in Cellular Tropism between Isolates of Equine Herpesvirus-1 in Foals. Archives of Virology, 74, 41-51. http://dx.doi.org/10.1007/BF01320781

[14] Kydd, J.H., Smith, K.C., Hannant, D., Livesay, G.J. and Mumford, J.A. (1994) Distribution of Equid Herpesvirus-1 (EHV-1) in the Respiratory Tract-Associated Lymphoid Tissue: Implications for Cellular Immunity. Equine Veterinary Journal, 26, 470-473. http://dx.doi.org/10.1111/j.2042-3306.1994.tb04052.x

[15] Allen, G.P. and Bryans, J.T. (1986) Molecular, Epizootiology, Pathogenesis and Prophylaxis of Equine Herpes Virus-1 Infections. Progress in Veterinary Microbiology and Immunology, 2, 78-144.

[16] Edington, N., Smyth, B. and Griffiths, L. (1991) The Role of Endothelial Cell Infection in the Endometrium, Placenta and Foetus of Equid Herpesvirus 1 (EHV-1) Abortions. Journal of Comparative Pathology, 104, 379-387. http://dx.doi.org/10.1016/S0021-9975(08)80148-X

[17] Smith, K.C., Whitwell, K.E., Binns, M.M., Dolby, C.A., Hannant, D. and Mumford, J.A. (1992) Abortion of Virologically Negative Foetuses Following Experimental Challenge of Pregnant Pony Mares with Equid Herpesvirus 1. Equine Veterinary Journal, 24, 256-259. http://dx.doi.org/10.1111/j.2042-3306.1992.tb02830.x

[18] Smith, K.C. and Borchers, K. (2001) A Study of the Pathogenesis of Equid Herpesvirus-1 (EHV-1) Abortion by DNA In-Situ Hybridization. Journal of Comparative Pathology, 125, 304-310. http://dx.doi.org/10.1053/jcpa.2001.0513

[19] Smith, K.L., Allen, G.P., Branscum, A.J., Frank Cook, R., Vickers, M.L., Timoney, P.J. and Balasuriya, U.B. (2010) The Increased Prevalence of Neuropathogenic Strains of EHV-1 in Equine Abortions. Veterinary Microbiology, 141, 5-11. http://dx.doi.org/10.1016/j.vetmic.2009.07.030

[20] Smith, K.C., Whitwell, K.E., Blunden, A.S., Bestbier, M.E., Scase, T.J., Geraghty, R.J., Nugent, J., Davis-Poynter, N.J. and Cardwell, J.M. (2004) Equine Herpesvirus-1 Abortion: Atypical Cases with Lesions Largely or Wholly Restricted to the Placenta. Equine Veterinary Journal, 36, 79-82. http://dx.doi.org/10.2746/0425164044864732

[21] Smith, K.C., Mumford, J.A. and Lakhani, K. (1996) A Comparison of Equid Herpesvirus-1 (EHV-1) Vascular Lesions in the Early versus Late Pregnant Equine Uterus. Journal of Comparative Pathology, 114, 231-247. http://dx.doi.org/10.1016/S0021-9975(96)80045-4

[22] Jackson, J.C., Golden, G.T. and Benjamin, R.M. (1977) The Distribution of Olfactory Input in the Opossum Mediodorsal Nucleus. Brain Research, 138, 229-240. http://dx.doi.org/10.1016/0006-8993(77)90742-9

[23] Platt, H., Singh, H. and Whitwellm, K.E. (1980) Pathological Observations on an Outbreak of Paralysis in Broodmares. 
Equine Veterinary Journal, 12, 118-126. http://dx.doi.org/10.1111/j.2042-3306.1980.tb03398.x

[24] Edington, N., Bridges, C.G. and Patel, J.R. (1986) Endothelial Cell Infection and Thrombosis in Paralysis Caused by Equid Herpesvirus-1: Equine Stroke. Archives of Virology, 90, 111-124. http://dx.doi.org/10.1007/BF01314149

[25] Roizman, B., Desrosiers, R.S., Fleckenstein, B., Lopez, C., Minson, A.C. and Studdert, M.J. (1992) The Family Herpesviridae: An Update. Archives of Virology, 123, 425-449. http://dx.doi.org/10.1007/BF01317276

[26] Edington, N., Welch, H.M. and Griffiths, L. (1994) The Prevalence of Latent Equid Herpesviruses in the Tissues of 40 Abattoir Horses. Equine Veterinary Journal, 26, 140-142. http://dx.doi.org/10.1111/j.2042-3306.1994.tb04353.x

[27] Slater, J.C., Borchers, K., Thackray, A.M. and Field, H. (1994) The Trigeminal Ganglion Is a Site of Equine Herpsvirus-1 (EHV-1) Latency and Reactivation in the Horse. Journal of General Virology, 75, 2007-2016. http://dx.doi.org/10.1099/0022-1317-75-8-2007

[28] Welch, H.M., Bridges, C.G., Lyon, A.M., Griffiths, L. and Edington, N. (1992) Latent Equid Herpesviruses 1 and 4 : Detection and Distinction Using the Polymerase Chain Reaction and Co-Cultivation from Lymphoid Tissues. Journal of General Virology, 73, 261-268. http://dx.doi.org/10.1099/0022-1317-73-2-261

[29] Chester, P.M., Allsop, R., Purewal, A. and Edington, N. (1997) Detection of Latency-Associated Transcripts of Equid Herpesvirus 1 in Equine Leukocytes but Not in Trigeminal Ganglia. Journal of Virology, 71, 3437-3443.

[30] Smith, P.M., Zhang, Y., Jennings, S.R. and O’Callaghan, D.J. (1998) Characterization of the Cytolytic T-Lymphocyte Response to a Candidate Vaccine Strain of Equine Herpesvirus 1 in CBA Mice. Journal of Virology, 72, 5366-5372.

[31] Chesters, P.M., Hughes, A. and Edington, N. (2000) Equid Herpesvirus 1: Platelets and Alveolar Macrophages Are Potential Sources of Activated TGF-B1 in the Horse. Veterinary Immunology and Immunopathology, 75, 71-79. http://dx.doi.org/10.1016/S0165-2427(00)00187-2

[32] Doll, E.R., Wallace, M.E., Bryans, J.T. and Richards, M.G. (1953) Complement-Fixation Antibody Response Following Administration of Equine Virus Abortion Vaccine. American Journal of Veterinary Research, 14, 46-48.

[33] Thomson, G.R., Mumford, J.A., Campbell, J., Griffiths, L. and Clapham, P. (1976) Serological Detection of Equid Herpesvirus 1 Infections of the Respiratory Tract. Equine Veterinary Journal, 8, 58-65. http://dx.doi.org/10.1111/j.2042-3306.1976.tb03291.X

[34] Allen, G., Coogle, L.D., Ostlund, E.N. and Yeargan, M.R. (1992) Molecular Dissection of Two Major Equine Herpesvirus-1 Glycoprotein Antigens (Gb and Gc) that Elicit Humoral Immune Responses in the Horse. In: Plowright, W., Rossdale, P.D. and Wade, J.F., Eds., Equine Infectious Diseases VI, R\&W Publications, Newmarket, 181-193.

[35] Fitzpatrick, D.R. and Studdert, M.J. (1984) Immunologic Relationships between Equine Herpesvirus Type 1 (Equine Abortion Virus) and Type 4 (Equine Rhinopneumonitis Virus). American Journal of Veterinary Research, 45, 19471952.

[36] Crabb, B.S. and Studdert, M.J. (1993) Epitopes of Glycoprotein G of Equine Herpesviruses 4 and 1 Located Near the C Termini Elicit Type Specific Antibody Responses in the Natural Host. Journal of Virology, 67, 6332-6338.

[37] Soboll Hussey, G., Hussey, S.B., Wagner, B., Horohov, D.W., Van De Walle, G.R., Osterrieder, N., Goehring, L.S., Rao, S. and Lunn, D.P. (2011) Evaluation of Immune Responses Following Infection of Ponies with an EHV-1 ORF1/2 Deletion Mutant. Veterinary Research, 42, 23. http://dx.doi.org/10.1186/1297-9716-42-23

[38] Crabb, B.S., Macpherson, C.M., Reubel, G.H., Browning, G.F., Studdert, M.J. and Drummer, H.E. (1995) A TypeSpecific Serological Test to Distinguish Antibodies to Equine Herpesviruses 4 and 1. Archives of Virology, 140, 245258. http://dx.doi.org/10.1007/BF01309860

[39] Soboll, G., Hussey, S.B., Whalley, J.M., Allen, G.P., Koen, M.T., Santucci, N., Fraser, D.G., Macklin, M.D., Swain, W.F. and Lunn, D.P. (2006) Antibody and Cellular Immune Responses Following DNA Vaccination and EHV-1 Infection of Ponies. Veterinary Immunology and Immunopathology, 111, 81-95. http://dx.doi.org/10.1016/j.vetimm.2006.01.011

[40] Mumford, E.L., Traub-Dargatz, J.L., Carman, J., Callan, R.J., Collins, J.K., Goltz, K.L., Romm, S.R., Tarr, S.F. and Salman, M.D. (2003) Occurrence of Infectious Upper Respiratory Tract Disease and Response to Vaccination in Horses on Six Sentinel Premises in Northern Colorado. Equine Veterinary Journal, 35, 72-77. http://dx.doi.org/10.2746/042516403775467379

[41] Sheoran, A.S., Lunn, D.P. and Holmes, M.A. (1998) Monoclonal Antibodies to Subclass-Specific Antigenic Determinants on Equine Immunoglobulin Gamma Chains and Their Characterization. Veterinary Immunology and Immunopathology, 62, 153-165. http://dx.doi.org/10.1016/S0165-2427(97)00162-1

[42] Lunn, D.P., Holmes, M.A., Schram, B. and Duffus, W.P. (1995) Monoclonal Antibodies Specific for Equine IgG SubIsotypes Including an Antibody Which Recognizes B Lymphocytes. Veterinary Immunology and Immunopathology, 47, 239-251. http://dx.doi.org/10.1016/0165-2427(95)97067-J

[43] Wagner, B., Miller, D.C., Lear, T.L. and Antczak, D.F. (2004) The Complete Map of the Ig Heavy Chain Constant Gene Region Reveals Evidence for Seven IgG Isotypes and for IgD in the Horse. Journal of Immunology, 173, 3230- 
3242. http://dx.doi.org/10.4049/jimmunol.173.5.3230

[44] Breathnach, C.C., Yeargan, M.R., Sheoran, A.S. and Allen, G.P. (2001) The Mucosal Humoral Immune Response of the Horse to Infective Challenge and Vaccination with Equine Herpesvirus-1 Antigens. Equine Veterinary Journal, 33, 651-657. http://dx.doi.org/10.2746/042516401776249318

[45] Ruitenberg, K.M., Love, D.N., Gilkerson, J.R., Wellington, J.E. and Whalley, J.M. (2000) Equine Herpesvirus 1 (EHV-1) Glycoprotein D DNA Inoculation in Horses with Pre-Existing EHV-1/EHV-4 Antibody. Veterinary Microbiology, 76, 117-127. http://dx.doi.org/10.1016/S0378-1135(00)00237-6

[46] Sheoran, A.S., Sponseller, B.T., Holmes, M.A. and Timoney, J.F. (1997) Serum and Mucosal Antibody Isotype Responses to M-Like Protein (Sem) of Streptococcus equi in Convalescent and Vaccinated Horses. Veterinary Immunology and Immunopathology, 59, 239-251. http://dx.doi.org/10.1016/S0165-2427(97)00074-3

[47] Nelson, K.M., Schram, B.R., Mcgregor, M.W., Sheoran, A.S., Olsen, C.W. and Lunn, D.P. (1998) Local and Systemic Isotype-Specific Antibody Responses to Equine Influenza Virus Infection versus Conventional Vaccination. Vaccine, 16, 1306-1313. http://dx.doi.org/10.1016/S0264-410X(98)00009-7

[48] Hannant, D., Easeman, R. and Mumford, J.A. (1999) Equine Mucosal Immune System: Intranasal Vaccination with Inactivated Equine Influenza Virus Protects from Infection. In: Wernery, O., Wade, J.F., Mumford, J.A. and Kaaden, O.R., Eds., Proceedings of the 8th International Conference on Equine Infectious Diseases, R\&W Publications Ltd., Newmarket, 50-56.

[49] Goodman, L.B., Wagner, B., Flaminio, M.J., Sussman, K.H., Metzger, S.M., Holland, R. and Osterrieder, N. (2006) Comparison of the Efficacy of Inactivated Combination and Modified-Live Virus Vaccines against Challenge Infection with Neuropathogenic Equine Herpesvirus Type 1 (EHV-1). Vaccine, 24, 3636-3645.

http://dx.doi.org/10.1016/j.vaccine.2006.01.062

[50] Paillot, R., Daly, J.M., Luce, R., Montesso, F., Davis-Poynter, N., Hannant, D. and Kydd, J.H. (2007) Frequency and Phenotype of EHV-1 Specific, IFN-Gamma Synthesizing Lymphocytes in Ponies: The Effects of Age, Pregnancy and Infection. Developmental and Comparative Immunology, 31, 202-214. http://dx.doi.org/10.1016/j.dci.2006.05.010

[51] Paillot, R., Daly, J.M., Juillard, V., Minke, J.M., Hannant, D. and Kydd, J.H. (2005) Equine Interferon Gamma Synthesis in Lymphocytes after in Vivo Infection and in Vitro Stimulation with EHV-1. Vaccine, 23, 4541-4551. http://dx.doi.org/10.1016/j.vaccine.2005.03.048

[52] Coombs, D.K., Patton, T., Kohler, A.K., Soboll, G., Breathnach, C., Townsend, H.G. and Lunn, D.P. (2006) Cytokine Responses to EHV-1 Infection in Immune and Non-Immune Ponies. Veterinary Immunology and Immunopathology, 111, 109-116. http://dx.doi.org/10.1016/j.vetimm.2006.01.013

[53] Wagner, B., Hillegas, J.M. and Antczak, D.F. (2006) A Monoclonal Antibody to Equine Interleukin 4. Veterinary Immunology and Immunopathology, 110, 363-367. http://dx.doi.org/10.1016/j.vetimm.2006.01.001

[54] Edington, N., Bridges, C.G. and Griffiths, L. (1989) Equine Interferons Following Exposure to Equid Herpesvirus-1 or -4. Journal of Interferon Research, 9, 389-392. http://dx.doi.org/10.1089/jir.1989.9.389

[55] Durbin, J.E., Fernandez-Sesma, A., Lee, C.K., Rao, T.D., Frey, A.B., Moran, T.M., Vukmanovic, S., García-Sastre, A. and Levy, D.E. (2000) Type I IFN Modulates Innate and Specific Antiviral Immunity. Journal of Immunology, 164, 4220-4228. http://dx.doi.org/10.4049/jimmunol.164.8.4220

[56] Ito, T., Wang, Y.H. and Liu, Y.J. (2005) Plasmacytoid Dendritic Cell Precursors/Type I Interferon-Producing Cells Sense Viral Infection by Toll-Like Receptor (TLR) 7 and TLR9. Springer Seminars in Immunopathology, 26, $221-229$. http://dx.doi.org/10.1007/s00281-004-0180-4

[57] Jung, A., Kato, H., Kumagai, Y., Kumar, H., Kawai, T., Takeuchi, O. and Akira, S. (2008) Lymphocytoid Choriomeningitis Virus Activates Plasmacytoid Dendritic Cells and Induces a Cytotoxic T-Cell Response via MyD88. Journal of Virology, 82, 196-206. http://dx.doi.org/10.1128/JVI.01640-07

[58] Szabo, G. and Dolganiuc, A. (2008) The Role of Plasmacytoid Dendritic Cell Derived IFN $\alpha$ in Antiviral Immunity. Critical Reviews in Immunology, 28, 61-94. http://dx.doi.org/10.1615/CritRevImmunol.v28.i1.40

[59] Pedersen, L.G., Castelruiz, Y., Jacobsen, S. and Aasted, B. (2002) Identification of Monoclonal Antibodies that CrossReact with Cytokines from Different Animal Species. Veterinary Immunology and Immunopathology, 88, 111-122. http://dx.doi.org/10.1016/S0165-2427(02)00139-3

[60] Breathnach, C.C., Soboll, G., Suresh, M. and Lunn, D.P. (2005) Equine Herpesvirus-1 Infection Induces IFN- $\gamma$ Production by Equine T Lymphocyte Subsets. Veterinary Immunology and Immunopathology, 103, 207-215. http://dx.doi.org/10.1016/j.vetimm.2004.09.024

[61] Paillot, R., Ellis, S.A., Daly, J.M., Audonnet, J.C., Minke, J.M., Davis-Poynter, N., Hannant, D. and Kydd, J.H. (2006) Characterisation of CTL and IFN- $\gamma$ Synthesis in Ponies Following Vaccination with a NYVAC-Based Construct Coding for EHV-1 Immediate Early Gene, Followed by Challenge Infection. Vaccine, 24, 1490-1500.

http://dx.doi.org/10.1016/j.vaccine.2005.10.019 
[62] Luce, R., Shepherd, M., Paillot, R., Blacklawst, B., Wood, J.L. and Kydd, J.H. (2007) Equine Herpesvirus-1-Specific Intereferon Gamma (IFN $\gamma$ ) Synthesis by Peripheral Blood Mononuclear Cells in Thoroughbred Horses. Equine Veterinary Journal, 39, 202-209. http://dx.doi.org/10.2746/042516407X174216

[63] Wagner, B., Hillegas, J.M., Brinker, D.R., Horohov, D.W. and Antczak, D.F. (2008) Characterization of Monoclonal Antibodies to Equine Interleukin-10 and Detection of T Regulatory 1 Cells in Horses. Veterinary Immunology and Immunopathology, 122, 57-64. http://dx.doi.org/10.1016/j.vetimm.2007.10.012

[64] Wagner, B., Hillegas, J.M., Flaminio, M.J.B.F. and Wattrang, E. (2008) Monoclonal Antibodies to Equine Interferon- $\alpha$ $($ IFN- $\alpha$ ): New Tools to Neutralize IFN Activity and to Detect Secreted IFN- $\alpha$. Veterinary Immunology and Immunopathology, 125, 315-325. http://dx.doi.org/10.1016/j.vetimm.2008.05.016

[65] Wagner, B. and Freer, H. (2009) Development of a Bead-Based Multiplex Assay for Simultaneous Quantification of Cytokines in Horses. Veterinary Immunology and Immunopathology, 127, 242-248. http://dx.doi.org/10.1016/j.vetimm.2008.10.313

[66] Soboll, G., Horohov, D.W., Aldridge, B.M., Olsen, C.W., Mcgregor, M.W., Drape, R.J., Macklin, M.D., Swain, W.F. and Lunn, D.P. (2003) Regional Antibody and Cellular Immune Responses to Equine Influenza Virus Infection, and Particle Mediated DNA Vaccination. Veterinary Immunology and Immunopathology, 94, 47-62. http://dx.doi.org/10.1016/S0165-2427(03)00060-6

[67] Breathnach, C.C., Rudersdorf, R. and Lunn, D.P. (2004) Use of Recombinant Modified Vaccinia Ankara Viral Vectors for Equine Influenza Vaccination. Veterinary Immunology and Immunopathology, 98, 127-136. http://dx.doi.org/10.1016/j.vetimm.2003.11.004

[68] Breathnach, C.C., Clark, H.J., Clark, R.C., Olsen, C.W., Townsend, H.G. and Lunn, D.P. (2006) Immunization with Recombinant Modified Vaccinia Ankara (rMVA) Constructs Encoding the HA or NP Gene Protects Ponies from Equine Influenza Virus Challenge. Vaccine, 24, 1180-1190. http://dx.doi.org/10.1016/j.vaccine.2005.08.091

[69] Fraser, D.G., Oaks, J.L., Brown, W.C. and Mcguire, T.C. (2002) Identification of Broadly Recognized, T Helper 1 Lymphocyte Epitopes in an Equine Lentivirus. Immunology, 105, 295-305. http://dx.doi.org/10.1046/j.0019-2805.2001.01370.x

[70] Fraser, D.G., Mealey, R.H. and Mcguire, T.C. (2003) Selecting Peptides to Optimize Th1 Responses to an Equine Lentivirus Using HLA-DR Binding Motifs and Defined HIV-1 Th Peptides. Immunogenetics, 55, 508-514. http://dx.doi.org/10.1007/s00251-003-0600-y

[71] Lopez, A.M., Hines, M.T., Palmer, G.H., Alperin, D.C. and Hines, S.A. (2002) Identification of Pulmonary T-Lymphocyte and Serum Antibody Isotype Responses Associated with Protection against Rhodococcus equi. Clinical and Diagnostic Laboratory Immunology, 9, 1270-1276.

[72] Pusterla, N., Wilson, W.D., Conrad, P.A., Barr, B.C., Ferraro, G.L., Daft, B.M. and Leutenegger, C.M. (2006) Cytokine Gene Signatures in Neural Tissue of Horses with Equine Protozoal Myeloencephalitis or Equine Herpes Type 1 Myeloencephalopathy. Veterinary Record, 159, 341-345. http://dx.doi.org/10.1136/vr.159.11.341

[73] Wagner, B., Burton, A. and Ainsworth, D.M. (2010) Interferon-Gamma, Interleukin-4 and Interleukin-10 Production by T Helper Cells Reveals Intact Th1 and Regulatory TR1 Cell Activation and a Delay of the Th2 Cell Response in Equine Neonates and Foals. Veterinary Research, 41, 47. http://dx.doi.org/10.1051/vetres/2010019

[74] Soboll, G., Breathnach, C.C., Kydd, J.H., Hussey, S.B., Mealey, R.M. and Lunn, D.P. (2010) Vaccination of Ponies with the IE Gene of EHV-1 in a Recombinant Modified Live Vaccinia Vector Protects against Clinical and Virological Disease. Veterinary Immunology and Immunopathology, 135, 108-117.

http://dx.doi.org/10.1016/j.vetimm.2009.11.009

[75] Dutta, S.K., Myrup, A. and Bumgardner, M.K. (1980) Lymphocyte Responses to Virus and Mitogen in Ponies during Experimental Infection with Equine Herpesvirus 1. American Journal of Veterinary Research, 41, 2066-2068.

[76] Hannant, D., O’Neill, T., Jessett, D.M. and Mumford, J.A. (1991) Evidence for Non-Specific Immunosuppression during the Development of Immune Responses to Equid Herpesvirus-1. Equine Veterinary Journal, 23, 41-45.

[77] Chong, Y.C. and Duffus, W.P. (1992) Immune Responses of Specific Pathogen Free Foals to EHV-1 Infection. Veterinary Microbiology, 32, 215-239. http://dx.doi.org/10.1016/0378-1135(92)90146-K

[78] Bumgardner, M.K., Dutta, S.K., Campbell, D.L. and Myrup, A.C. (1982) Lymphocytes from Ponies Experimentally Infected with Equine Herpesvirus 1: Subpopulation Dynamics and Their Response to Mitogens. American Journal of Veterinary Research, 43, 1308-1310.

[79] Charan, S., Palmer, K., Chester, P., Mire-Sluis, A.R., Meager, A. and Edington, N. (1997) Transforming Growth Factor- $\beta$ Induced by Live or Ultraviolet-Inactivated Equid Herpes Virus Type-1 Mediates Immunosuppression in the Horse. Immunology, 90, 586-591. http://dx.doi.org/10.1046/j.1365-2567.1997.00202.x

[80] Van Der Meulen, K.M., Favoreel, H.W., Pensaert, M.B. and Nauwynck, H.J. (2006) Immune Escape of Equine Herpesvirus 1 and Other Herpesviruses of Veterinary Importance. Veterinary Immunology and Immunopathology, 111, 31- 
40. http://dx.doi.org/10.1016/j.vetimm.2006.01.006

[81] Kydd, J.H., Hannant, D. and Mumford, J.A. (1996) Residence and Recruitment of Leucocytes to the Equine Lung after EHV-1 Infection. Veterinary Immunology and Immunopathology, 52, 15-26. http://dx.doi.org/10.1016/0165-2427(95)05533-9

[82] Lunn, D.P., Holmes, M.A. and Duffus, W.P. (1991) Three Monoclonal Antibodies Identifying Antigens on All Equine T Lymphocytes, and Two Mutually Exclusive T-Lymphocyte Subsets. Immunology, 74, 251-257.

[83] Allen, G.P., Kydd, J.H., Slater, J.D. and Smith, K.C. (1999) Advances in Understanding of the Pathogenesis, Epidemiology, and Immunological Control of Equid Herpesvirus Abortion. In: Wernery, U., Wade, J.F., Mumford, J.A. and Kaaden, O.R., Eds., Equine Infectious Diseases VIII. Proceedings of the 8th International Conference, R \& W Publications, Newmarket, 129-146.

[84] O’Neill, T., Kydd, J.H., Allen, G.P., Wattrang, E., Mumford, J.A. and Hannant, D. (1999) Determination of Equid Herpesvirus 1-Specific, CD8 ${ }^{+}$, Cytotoxic T Lymphocyte Precursor Frequencies in Ponies. Veterinary Immunology and Immunopathology, 70, 43-54. http://dx.doi.org/10.1016/S0165-2427(99)00037-9

[85] Siedek, E.M., Whelan, M., Edington, N. and Hamblin, A. (1999) Equine Herpesvirus Type 1 Infects Dendritic Cells in Vitro: Stimulation of T Lymphocyte Proliferation and Cytotoxicity by Infected Dendritic Cells. Veterinary Immunology and Immunopathology, 67, 17-32. http://dx.doi.org/10.1016/S0165-2427(98)00203-7

[86] Hannant, D., O’Neill, T., Ostlund, E.N., Kydd, J.H., Hopkin, P.J. and Mumford, J.A. (1999) Equid Herpesvirus-Induced Immunosuppression Is Associated with Lymphoid Cells and Not Soluble Circulating Factors. Viral Immunology, 12, 313-321. http://dx.doi.org/10.1089/vim.1999.12.313

[87] O’Neill, T. (1995) T Lymphocyte Responses to Equid Herpesviruses-1 and -4 in Horses. Ph.D. Thesis, Open University, London.

[88] Scott, J.C., Dutta, S.K. and Myrup, A.C. (1983) In Vivo Harboring of Equine Herpesvirus-1 in Leukocyte Populations and Subpopulations and Their Quantitation from Experimentally Infected Ponies. American Journal of Veterinary Research, 44, 1344-1348.

[89] Dutta, S.K. and Myrup, A.C. (1983) Infectious Center Assay of Intracellular Virus and Infective Virus Titer for Equine Mononuclear Cells Infected in Vivo and in Vitro with Equine Herpesviruses. Canadian Journal of Comparative Medicine, 47, 64-69.

[90] Van Der Meulen, K.M., Nauwynck, H.J., Buddaert, W. and Pensaert, M.B. (2000) Replication of Equine Herpesvirus Type 1 in Freshly Isolated Equine Peripheral Blood Mononuclear Cells and Changes in Susceptibility Following Mitogen Stimulation. Journal of General Virology, 81, 21-25.

[91] Gryspeerdt, A.C., Vandekerckhove, A.P., Garre, B., Barbe, F., Van De Walle, G.R. and Nauwynck, H.J. (2010) Differences in Replication Kinetics and Cell Tropism between Neurovirulent and Non-Neurovirulent EHV1 Strains during the Acute Phase of Infection in Horses. Veterinary Microbiology, 142, 242-253. http://dx.doi.org/10.1016/j.vetmic.2009.10.015

[92] Goodman, L.B., Loregian, A., Perkins, G.A., Nugent, J., Buckles, E.L., Mercorelli, B., Kydd, J.H., Palù, G., Smith, K.C., Osterrieder, N. and Davis-Poynter, N. (2007) A Point Mutation in a Herpesvirus Polymerase Determines Neuropathogenicity. PLoS Pathogens, 3, e160. http://dx.doi.org/10.1371/journal.ppat.0030160

[93] Wilsterman, S., Soboll-Hussey, G., Lunn, D.P., Ashton, L.V., Callan, R.J., Hussey, S.B., Rao, S. and Goehring, L.S. (2011) Equine Herpesvirus-1 Infected Peripheral Blood Mononuclear Cell Subpopulations during Viremia. Veterinary Microbiology, 149, 40-47. http://dx.doi.org/10.1016/j.vetmic.2010.10.004

[94] Ambagala, A.P.N., Gopinath, R.S. and Srikumaran, S. (2004) Peptide Transport Activity of the Transporter Associated with Antigen Processing (TAP) Is Inhibited by an Early Protein of Equine Herpesvirus-1. Journal of General Virology, 85, 349-353. http://dx.doi.org/10.1099/vir.0.19563-0

[95] Favoreel, H.W., Van Minnebruggen, G., Van De Walle, G.R., Ficinska, J. and Nauwynck, H.J. (2006) Herpesvirus Interference with Virus-Specific Antibodies: Bridging Antibodies, Internalizing Antibodies, and Hiding from Antibodies. Veterinary Microbiology, 113, 257-263. http://dx.doi.org/10.1016/j.vetmic.2005.11.003

[96] Van De Walle, G.R., May, M.L., Sukhumavasi, W., Von Einem, J. and Osterrieder, N. (2007) Herpesvirus ChemokineBinding Glycoprotein G (gG) Efficiently Inhibits Neutrophil Chemotaxis in Vitro and in Vivo. Journal of Immunology, 179, 4161-4169. http://dx.doi.org/10.4049/jimmunol.179.6.4161

[97] Van De Walle, G.R., Goupil, R., Wishon, C., Damiani, A., Perkins, G.A. and Osterrieder, N. (2009) A Single-Nucleotide Polymorphism in a Herpesvirus DNA Polymerase Is Sufficient to Cause Lethal Neurological Disease. Journal of Infectious Diseases, 200, 20-25.

[98] Van De Walle, G.R., Jarosinski, K.W. and Osterrieder, N. (2008) Alphaherpesviruses and Chemokines: Pas De Deux Not Yet Brought to Perfection. Journal of Virology, 82, 6090-6097. http://dx.doi.org/10.1128/JVI.00098-08

[99] Stokes, A. and Wardley, R.C. (1988) ADCC and Complement-Dependent Lysis as Immune Mechanisms against 
EHV-1 Infection in the Horse. Research in Veterinary Science, 44, 295-302.

[100] Huemer, H.P., Nowotny, N., Crabb, B.S., Meyer, H. and Hübert, P.H. (1995) gp13 (EHV-gC): A Complement Receptor Induced by Equine Herpesviruses. Virus Research, 37, 113-126. http://dx.doi.org/10.1016/0168-1702(95)00027-N

[101] Rappocciolo, G., Birch, J. and Ellis, S.A. (2003) Down-Regulation of MHC Class I Expression by Equine Herpesvirus-1. Journal of General Virology, 84, 293-300. http://dx.doi.org/10.1099/vir.0.18612-0

[102] Nugent, J., Birch-Machin, I., Smith, K.C., Mumford, J.A., Swann, Z., Newton, J.R., Bowden, R.J., Allen, G.P. and Davis-Poynter, N. (2006) Analysis of Equid Herpesvirus 1 Strain Variation Reveals a Point Mutation of the DNA Polymerase Strongly Associated with Neuropathogenic versus Nonneuropathogenic Disease Outbreaks. Journal of Virology, 80, 4047-4060. http://dx.doi.org/10.1128/JVI.80.8.4047-4060.2006

[103] Van Der Meulen, K.M., Nauwynck, H.J. and Pensaert, M.B. (2003) Absence of Viral Antigens on the Surface of Equine Herpesvirus-1-Infected Peripheral Blood Mononuclear Cells: A Strategy to Avoid Complement-Mediated Lysis. Journal of General Virology, 84, 93-97. http://dx.doi.org/10.1099/vir.0.18864-0

[104] Crabb, B.S. and Studdert, M.J. (1996) Equine Rhinopneumonitis (Equine Herpesvirus 4) and Equine Abortion (Equine Herpesvirus 1). In: Studdert, M.J., Ed., Virus Infections of Equines, Elsevier Sciences, 11-37.

[105] Slater, J. and Hannant, D. (2000) Equine Immunity to Viruses. Veterinary Clinics of North America, 16, 49-68.

[106] Mumford, J.A., Rossdale, P.D., Jessett, D.M., Gann, S.J., Ousey, J. and Cook, R.F. (1987) Serological and Virological Investigations of an Equid Herpesvirus 1 (EHV-1) Abortion Storm on a Stud Farm in 1985. Journal of Reproduction and Fertility Supplement, 35, 509-518.

[107] Rosas, C.T., Goodman, L.B., Von Einem, J. and Osterrieder, N. (2006) Equine Herpesvirus Type 1 Modified Live Virus Vaccines: Quo vaditis? Expert Review of Vaccines, 5, 119-131. http://dx.doi.org/10.1586/14760584.5.1.119 


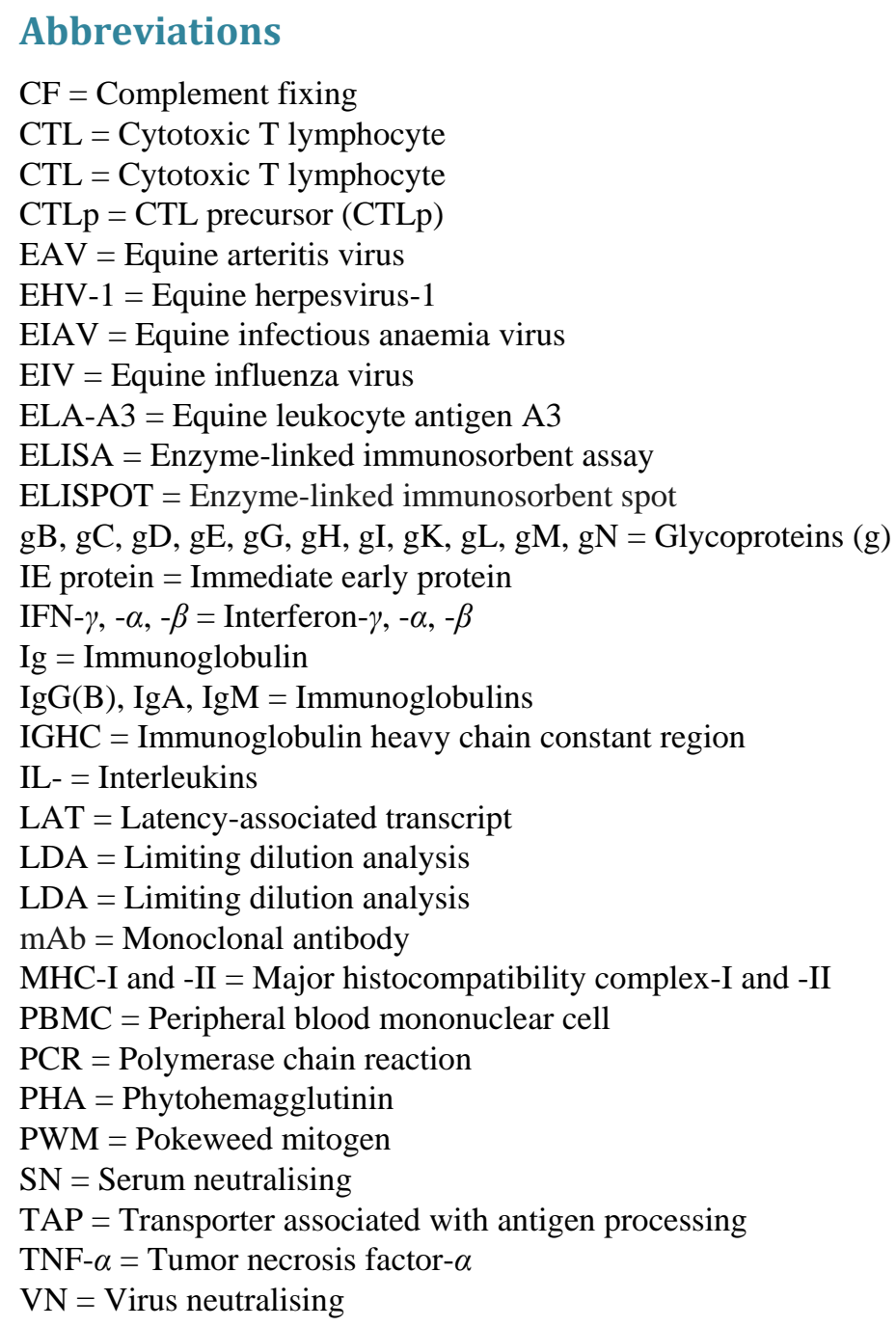


Scientific Research Publishing (SCIRP) is one of the largest Open Access journal publishers. It is currently publishing more than 200 open access, online, peer-reviewed journals covering a wide range of academic disciplines. SCIRP serves the worldwide academic communities and contributes to the progress and application of science with its publication.

Other selected journals from SCIRP are listed as below. Submit your manuscript to us via either submit@scirp.org or Online Submission Portal.
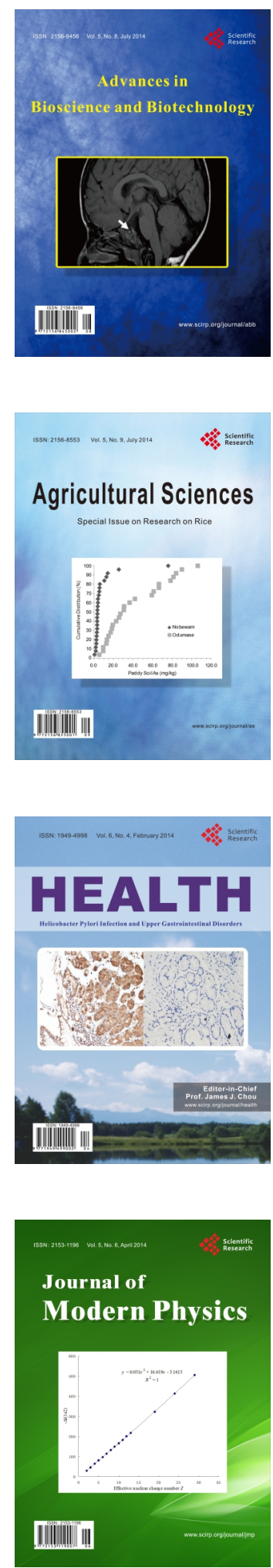
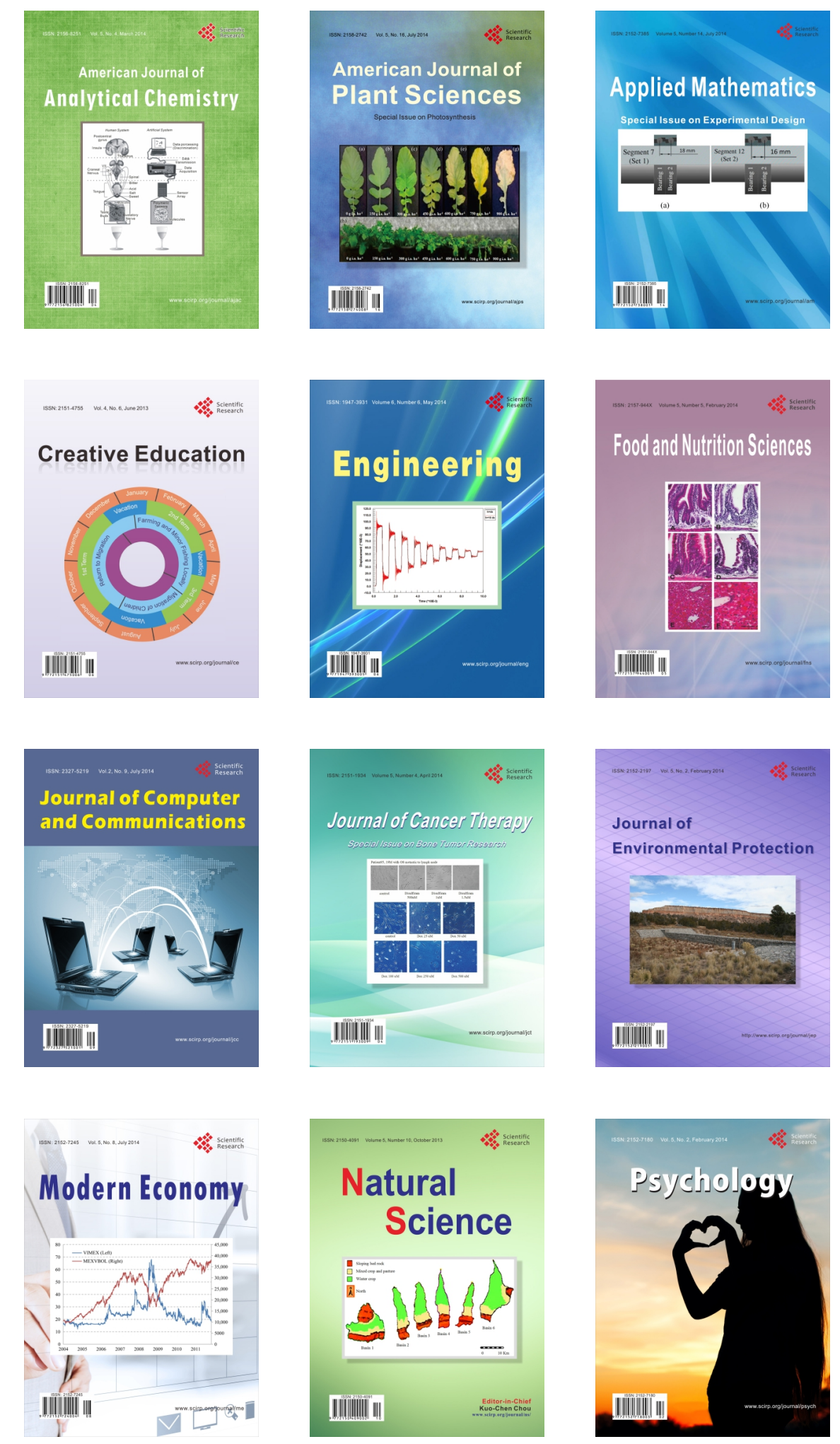